\title{
Optimization of enzymatic hydrolysis for bioethanol production by semi- simultaneous saccharification and fermentation using mature coconut fibre
}

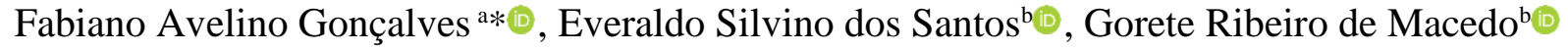 \\ a Federal Institute of Education, Science and Technology of Mato Grosso, Brazil \\ b Federal University of Rio Grande do Norte, Brazil \\ *Autor correspondent (fabiano_avelinogoncalves@yahoo.com.br)
}

\section{N F O}

\section{Keywords}

Lichtheimia ramosa, crude enzyme extract, $\beta$-glucosidase, wheat bran, SSSF

\begin{abstract}
A B S T R A C T
Alternative substrates to produce useful chemicals such as biofuel have been attractive, in particular, for cellulosic ethanol production. In this context, the objective of this work was optimized the synergistic mixture of enzymes and bioethanol production. The enzymes of Trichoderma reesei and crude enzyme extract from Lichtheimia ramosa were used in the hydrolysis of mature coconut fibre pretreated by sequential process of alkaline hydrogen peroxide $\left(\mathrm{Alk}-\mathrm{H}_{2} \mathrm{O}_{2}\right)$-sodium hydroxide $(\mathrm{NaOH})$. Furthermore, these enzymes and pretreated vegetable biomass were applied in the bioethanol production by Saccharomyces cerevisiae in semi-simultaneous saccharification and fermentation strategy (SSSF). Resulting in the yields and conversions of delignified mature coconut fibre into reducing sugars between 12.7-82.14\% and 0.09-0.64 g reducing sugars/g dry biomass, respectively, with an initial hydrolysis rate at $12 \mathrm{~h}$ between $0.10-0.89 \mathrm{~g} /(\mathrm{L} . \mathrm{h})$. Yields and conversions of delignified mature coconut fibre into glucose between $10.16-83.78 \%$ and $0.06-0.43 \mathrm{~g}$ glucose/g dry biomass, in that order, with an initial hydrolysis rate at $12 \mathrm{~h}$ between $0.03-0.35 \mathrm{~g} /(\mathrm{L} . \mathrm{h})$. Bioethanol production by $S$. cerevisiae using delignified mature coconut fibre, enzymes from $T$. reese $i$ and crude enzyme extract from $L$. ramosa resulted in the production of $4.62 \mathrm{~g} / \mathrm{L}$, yield of $0.41 \mathrm{~g}$ ethanol/g glucose and volumetric productivity of ethanol of $0.13 \mathrm{~g} /(\mathrm{L} . \mathrm{h})$, respectively. The results showed synergistic effects between enzymes from $T$. reesei and crude enzyme extract from L. ramosa, without promoting inhibition in the alcoholic fermentation. Therefore, allowing to formulate an optimized enzymatic preparation aiming cellulosic ethanol production.
\end{abstract}

\section{R E S U M O}

Otimização da hidrólise enzimática para produção de bioetanol por sacarificação e fermentação semisimultâneas usando fibra de coco maduro

Substratos alternativos para produzir produtos químicos úteis, como biocombustível, têm sido atraentes, principalmente para a produção de etanol celulósico. Neste contexto, o objetivo deste trabalho foi otimizar a mistura sinérgica de enzimas de Trichoderma reesei e extrato de enzima bruta de Lichtheimia ramosa para a hidrólise da fibra de coco maduro pré-tratado com peróxido de hidrogênio alcalino $\left(\mathrm{Alk}-\mathrm{H}_{2} \mathrm{O}_{2}\right)$ hidróxido de sódio $(\mathrm{NaOH})$ e produção de bioetanol por Saccharomyces cerevisiae em estratégia de sacarificação e fermentação semi-simultânea (SSSF). Resultando nas conversões e rendimentos de fibra de coco maduro deslignificada em açúcares redutores entre 12,0-82,3\% e 0,09-0,64 g de açúcares redutores/g de biomassa seca, respectivamente, com uma taxa de hidrólise inicial em $12 \mathrm{~h}$ entre $0,10-0,89$ $\mathrm{g} /(\mathrm{Lh})$. As conversões e rendimentos de fibra de coco maduro deslignificado em glicose entre 10,4-83,9\% e 0,06-0,43 g de glicose/g de biomassa seca, nessa ordem, com uma taxa de hidrólise inicial em $12 \mathrm{~h}$ entre 0,03-0,35 g/(L.h). A produção de bioetanol por $S$. cerevisiae utilizando fibra de coco maduro deslignificado, enzimas de $T$. reesei e extrato de enzima bruta de L. ramosa resultou na produção, rendimento e produtividade volumétrica de etanol de 4,62 $\mathrm{g} / \mathrm{L}, 0,41 \mathrm{~g}$ de etanol/g de glicose e $0,13 \mathrm{~g} /(\mathrm{Lh})$, respectivamente. Os resultados mostraram efeitos sinérgicos entre as enzimas de $T$. reesei e extrato bruto de L. ramosa, além de não promover inibição na fermentação alcoólica. Portanto, permitindo formular uma preparação enzimática otimizada visando a produção de etanol celulósico. 


\section{INTRODUCTION}

Climate change and the rising price of oil barrel, added to the energy production needs, motivate the fuels production from renewable sources. Thus, lignocellulosic materials are considered promising alternatives for biofuels production, enzymes and other useful chemicals, because of its abundance and renewable nature (Gonçalves et al., 2011, 2013a, 2013b; Billard et al., 2012; Saini et al., 2013; Pandit et al., 2013; Zimbardi et al., 2013; Gonçalves et al., 2015; Gonçalves et al., 2019). Lignocellulosic materials used in this work for bioethanol and enzymes production have ample abundance, for example, coconut trees have ideal growing conditions in a humid tropical climate and are distributed in over 200 countries (FAO, 2012), mainly derived from the Philippines, Indonesia, India and Sri Lanka. Brazil is the fifth largest producer of coconut, with production of approximately 1.5 million tons (IBGE, 2020). Due to this breakthrough, the production chain of coconut does not have the correct destination of their agro-industrial and urban waste. Furthermore, wheat bran used in this work is also a good carbon source for lignocellulolytic enzymes production by different microorganisms using in the solid state bioprocessing (SSB), even in the absence of any supplementary carbon or nitrogen sources (Leite et al., 2007; Gonçalves et al., 2013a; Zimbardi et al., 2013; Garcia et al., 2018).

SSB resembles the natural environment of the microorganisms and has tremendous potential for enzymes production (Pandit et al., 2013). Besides, the SSB has some advantages over submerged bioprocessing $(\mathrm{SmB})$, including the superior productivity, simple technique, low capital investment, low energy requirement and less wastewater output and better product recovery (Pandey, 2003). Several types of microorganisms are used in SSB, highlighting of the filamentous fungi (Rocha et al., 2013).

Three categories of enzymes are necessary to convert cellulose into glucose. These include endoglucanase which hydrolyzes internal $\beta-1,4-$ glucosidic bonds randomly in the cellulose chain, cellobiohydrolase which moves progressively along the cellulose chain and cleave off cellobiose units from the ends of the chain, $\beta$-glucosidase, which converts cellobiose and soluble cellodextrins into glucose (Zhou et al., 2009; Singh and Bishnoi, 2012; Zimbardi et al., 2013). But lacking in $\beta$ glucosidase production, cause accumulation of cellobiose, which produces repression and endproduct inhibition during hydrolysis (Berlin et al., 2007; Singh and Bishnoi, 2012; Gupta and Lee, 2013; Singhania et al., 2013; Zimbardi et al., 2013).

Furthermore, application of cellulases for conversion of lignocellulosic material to ethanol has been investigated for a long time, and it is now well-known that a mixture of different cellulolytic activities is necessary for the hydrolysis of cellulose into glucose for fermentation into ethanol (Zhou et al., 2009; Gupta and Lee, 2013). An optimized enzyme mixture is crucial for reduced cost of enzymatic hydrolysis step in the bioethanol production process and its composition will depend on the substrate and the type of pretreatment used (Billard et al., 2012; Wang et al., 2013). Individual cellulases have very limited hydrolytic activity while a mixture of cellulases can exhibit a synergistic effect where the hydrolytic activity of the cellulase mixture is greater than the sum of the hydrolytic activities of the individual enzyme (Zhou et al., 2009; Rana et al., 2014). Trichoderma reesei is the major fungus used for industrial cellulase production (Zhou et al., 2009; Billard et al., 2012; Singh and Bishnoi, 2012; Rocha et al., 2013; Singhania et al., 2013), and the ratio of $\beta$ glucosidase in commercial enzymatic preparations used today from $T$. reesei for cellulosic ethanol production is often low (Wang et al., 2013) and once purity is not a prerequisite for various industrial applications, may then be directly employed crude enzyme extracts (Zimbardi et al., 2013), as in this work, to complement the ratio of $\beta$-glucosidase.

Therefore, in this work it will be produced enzymes from Lichtheimia ramosa that has been isolated by Gonçalves et al. (2013a). Although, initially described as belonging to a genus of pathogenic microorganism (Borrás et al., 2010; Schwartze et al., 2012; Bibashi et al., 2013), this microorganism has advantage of presenting rapid cell growth (Gonçalves et al., 2013a; Silva et al., 2014), as well as it presents potential for the bioproduct production, as described by Gonçalves et al. (2013a) that produced the enzymes CMCase, xylanase and $\beta$-glucosidase by the $L$. ramosa using sugarcane bagasse and wheat bran as substrate in SSB with emphasis on the $\beta$-glucosidase activity achieving $15.58 \mathrm{IU} / \mathrm{mL}$ when wheat bran was used as substrate. This recent discovery of cellulases productions and hemicellulases by $L$. ramosa arises the need of verifying the applicability of the enzyme complex produced by this microorganism, as well as the enzyme pool in order to perform efficient hydrolysis of the lignocellulosic materials. Furthermore, Silva et al. (2013) carried out amylases production, $\beta$-glucosidases, CMCase and xylanases in SSB utilizing wastes of the Brazilian savannah fruits. In addition, Ferreira et al. (2013) have reported invertase production by $L$. ramosa.

However, lignocellulosic materials cannot be easily converted to simple monomeric sugars due 
to the recalcitrant nature of these molecules. To make cellulose and hemicellulose available for the attack of cellulases and hemicellulases, pretreatments are generally used (Adsul et al., 2005). Pretreatment processes can be physical, chemical, biological or a combination of these methods (Gonçalves et al., 2013b; Gonçalves et al., 2015). That way, economics and environmental sustainability in the bioethanol production process is always affected by the cost of pretreatment (Singh et al., 2010) and commercial enzymatic preparation (Gupta and Lee, 2013; Zimbardi et al., 2013).

In the present work will be used an alkaline hydrogen peroxide pretreatment $\left(\mathrm{Alk}-\mathrm{H}_{2} \mathrm{O}_{2}\right)$ followed by sodium hydroxide pretreatment $(\mathrm{NaOH})$ in mature coconut fibre. Hydrogen peroxide and sodium hydroxide react with lignin under certain conditions and has been widely used as bleaching in highly lignified wood pulps (Carvalheiro et al., 2008). Alk- $\mathrm{H}_{2} \mathrm{O}_{2}$ pretreatment leaves no residue in the biomass and the peroxide decomposes into oxygen and water (Carvalheiro et al., 2008). This is a great advantage, because water consumption is a critical factor for bioethanol production, as well as there are absence of waste treatment and effluent (Rabelo et al., 2011). The potential use of $\mathrm{NaOH}$ pretreatment was examined in some works, among which the most cases showed the greatest effect of this pretreatment under a variety of lignocellulosic materials, as sugarcane bagasse (Santos and Gouveia, 2009), coastal Bermuda grass (Wang et al., 2010) and coconut fibre mature (Gonçalves et al., 2016).

In general, after the pretreatment stage, the enzymatic hydrolysis and fermentation may be carried out in separate stages or simultaneously as separate hydrolysis and fermentation (SHF) and simultaneous saccharification and fermentation (SSF) are commonly used. However, arose the possibility of junction of the SHF and SSF creating semi-simultaneous saccharification and fermentation (SSSF) from blend the advantages afforded by SSF and SHF, which includes a presaccharification stage and SSF (Shen and Agblevor, 2010; Mesa et al., 2011; Gonçalves et al., 2014; Gonçalves et al., 2016).

In this context, the aim of this work was to optimize the synergistic mixture of enzymes from $T$. reesei and crude enzyme extract from $L$. ramosa in the hydrolysis of mature coconut fibre pretreated by Alk- $\mathrm{H}_{2} \mathrm{O}_{2} / \mathrm{NaOH}$ as well as the bioethanol production by $S$. cerevisiae using SSSF strategy.

\section{MATERIAL AND METHODS}

\section{Enzyme production}

\section{Raw material for enzyme production}

Wheat bran, a byproduct of flour production was obtained from Dias Branco Flour Mill, located in Natal, RN, Brazil. Wheat bran substrate was washed with distilled water and then oven-dried at $50{ }^{\circ} \mathrm{C}$, during $48 \mathrm{~h}$. According to Rostagno (2011), wheat bran has the following composition: $31 \%$ cellulose, $26 \%$ hemicellulose, $14 \%$ lignin, $15 \%$ protein, $4 \%$ lipids and $7 \%$ ash.

\section{Microorganism and solid solid-state bioprocessing -state bioprocessing (SSB) for enzyme production}

Microorganism used was L. ramosa, isolated by Gonçalves et al. (2013a) and maintained in the microbiological collection of Laboratory of Bioengineering at the Federal University of Grande Dourados, Dourados, MS, Brazil.

\section{Preculture and inoculation}

Microorganism was precultivated in $125 \mathrm{~mL}$ Erlenmeyer flasks containing $20 \mathrm{~mL}$ of culture medium of potato dextrose agar (PDA), stored in a BOD chamber by $120 \mathrm{~h}$ at $35^{\circ} \mathrm{C}$ and then suspended in $25 \mathrm{~mL}$ saline solution $(0.1 \%$ ammonium sulfate, $0.1 \%$ heptahydrate magnesium sulfate and $0.1 \%$ ammonium nitrate) constituting the microbial suspension. Inoculation was performed by transferring $10 \mathrm{~mL}$ of microbial suspension to the $250 \mathrm{~mL}$ Erlenmeyer flasks containing culture medium based on wheat bran, constituted by $5 \mathrm{~g}$ of wheat bran moistened with 5 $\mathrm{mL}$ of saline solution (moisture content was about 70\%) (Leite et al., 2007), the SSB was maintained at $35{ }^{\circ} \mathrm{C}$, during $120 \mathrm{~h}$ (Gonçalves et al., 2013a). The materials were previously autoclaved at $121{ }^{\circ} \mathrm{C}$ by $20 \mathrm{~min}$.

\section{Enzymatic extraction}

For enzymatic extraction, $50 \mathrm{~mL}$ of distilled water were added to Erlenmeyer flasks containing the culture medium based on wheat bran. The culture medium was left during $1 \mathrm{~h}$ in an orbital shaker $\left(60 \mathrm{rpm}\right.$ and $\left.25^{\circ} \mathrm{C}\right)$ and then filtered through synthetic filters, yielding the crude enzyme extract (Leite et al., 2007) and maintained at $4{ }^{\circ} \mathrm{C}$.

\section{Enzymes of $T$, reesei}

The enzymes of $T$. reesei ATCC 26921 (Cellubrix) was obtained from Sigma A/S and it was used in the experimental design for hydrolysis of the delignified mature coconut fibre (Table 1). 


\section{Enzymatic activities}

The enzymatic activities of cellulases, $\beta$ glucosidase and xylanase were determined in the crude enzyme extract from $L$. ramosa and enzymes from $T$. reesei.

\section{Cellulase activity}

Total cellulase activity was analysed in accordance with the standard methodology established by Mandels et al. (1976). In a test tube were added $0.3 \mathrm{~mL}$ of diluted enzyme, $1.2 \mathrm{~mL}$ of sodium citrate buffer $(0.5 \mu \mathrm{M}$ at $\mathrm{pH} 4.8)$ and $50 \mathrm{mg}$ Whatman filter paper No. 1 as substrate. The medium was incubated in a heater device at $50{ }^{\circ} \mathrm{C}$, during $1 \mathrm{~h}$ and the glucose liberated was measured using the DNS method described by Ghose (1987). DNS reagent reacts with reducing sugars to form 3amino-5-nitrosalicylic acid, which absorbs light at $540 \mathrm{~nm}$.

\section{$\beta$-glucosidase activity}

The $\beta$-glucosidase activity was measured by incubating the enzymatic solution with $15 \mu \mathrm{M}$ of cellobiose and $50 \mathrm{mM}$ sodium citrate buffer $(\mathrm{pH}$ 4.8 ) at $50{ }^{\circ} \mathrm{C}$, during $30 \mathrm{~min}$. The reaction was stopped, immersing the test tubes into boiling water during $5 \mathrm{~min}$. Then, the glucose concentration was determined by the glucose oxidase (GOD) and peroxidase (POD) method (GOD-POD test kit, Accurex Biomedical Pvt., India), applied at $25^{\circ} \mathrm{C}$, during 10 min with the produced amount of glucose measured spectrophotometrically at $500 \mathrm{~nm}$. Glucose oxidase converts glucose to gluconic acid and hydrogen peroxide, posteriorly the peroxide oxidatively couples with 4-aminoantipyrene and phenol in the presence of peroxidase to produce a red quinoeimine dye that absorbs light at $500 \mathrm{~nm}$. One unit of enzyme activity $(\mathrm{CBU} / \mathrm{mL})$ was defined as the amount of enzyme that released 1 $\mu$ mol of glucose per min under the assay conditions.

\section{Xylanase activity}

The ylanase activity was determined using a reaction mixture contained $0.1 \mathrm{~mL}$ enzyme and $0.5 \%(\mathrm{w} / \mathrm{v})$ of oat spelts xylan solution (Sigma A/S) in acetate buffer ( $\mathrm{pH}$ 5.0). The mixture was incubated at $50{ }^{\circ} \mathrm{C}$, during $10 \mathrm{~min}$. After predetermined period, the released reducing sugars were quantified by DNS method recorded spectrophotometrically at $540 \mathrm{~nm}$ (Ghose, 1987). One unit of xylanase activity $(\mathrm{UI} / \mathrm{mL})$ was defined as the amount of enzyme that released $1 \mu \mathrm{mol}$ of xylose per min under the assay conditions.

\section{Raw material for enzymatic hydrolysis and bioethanol production}

Mature coconut fibre was obtained from the agroindustries located in the Northeast of Brazil. The assays in order to obtain the composition of the raw material was carried out as Gonçalves et al. (2014).

\section{Pretreatment process}

\section{Preparation of raw material before the pretreatment}

Mature coconut fibre was washed five times with distilled water at $70{ }^{\circ} \mathrm{C}$ for removal of residual compounds present in the material. After this procedure, the material was dried in an oven with air circulation at $40{ }^{\circ} \mathrm{C}$, during $24 \mathrm{~h}$. The material was milled using a knife mills and standardized into a particle size of 48 mesh $(0.3 \mathrm{~mm})$.

\section{Alkaline hydrogen peroxide pretreatment (Alk- $\mathrm{H}_{2} \mathrm{O}_{2}$ )}

Alk- $\mathrm{H}_{2} \mathrm{O}_{2}$ pretreatment was carried out according to Rabelo et al. (2011). $0.4 \mathrm{~g}$ of mature coconut fibre was mixed with $31.75 \mathrm{~mL}$ of hydrogen peroxide (concentration of $7.35 \%(\mathrm{v} / \mathrm{v})$ ) in a flask at $25^{\circ} \mathrm{C}$, during $1 \mathrm{~h}$ with agitation at 150 $\mathrm{rpm}$. The $\mathrm{pH}$ of hydrogen peroxide solution was adjusted. The material residual solid was separated via vacuum filtration and washed with distilled water.

\section{Delignification process with sodium hydroxide (NaOH)}

Mature coconut fibre pretreated by Alk- $\mathrm{H}_{2} \mathrm{O}_{2}$ was transferred to a flask with $4 \%(\mathrm{w} / \mathrm{v})$ solution of sodium hydroxide. The mixture remained at $100{ }^{\circ} \mathrm{C}$ under agitation of $100 \mathrm{rpm}$, during $1 \mathrm{~h}$. After the delignification process, the solid was separated from the liquor by filtration. The solid was submitted to seven washes with distilled water (Gouveia and Santos, 2009)

\section{Enzymatic hydrolysis}

\section{Process of enzymatic hydrolysis}

Mature coconut fibre pretreated by Alk$\mathrm{H}_{2} \mathrm{O}_{2} / \mathrm{NaOH}$ was used as substrate in the enzymatic hydrolysis (EH). The EH were performed with $2 \%$ 
of delignified mature coconut fibre in $250 \mathrm{~mL}$ Erlenmeyer flask containing a volume of $48 \mathrm{~mL}$ at $50{ }^{\circ} \mathrm{C}$, agitation at $150 \mathrm{rpm}$, during $96 \mathrm{~h}$ using crude enzyme extract from $L$. ramosa and enzymes from T. reesei (see Table 1) in $50 \mathrm{mM}$ sodium citrate buffer with $0.02 \%(\mathrm{w} / \mathrm{v})$ sodium azide to prevent microbial growth. The samples were taken at $6 \mathrm{~h}$ intervals for the first $12 \mathrm{~h}$ and every $12 \mathrm{~h}$ intervals until a total time of $96 \mathrm{~h}$ (Dowe and Mcmillan, 2001; Santos et al., 2010). All determinations were performed in duplicate. The total reducing sugars (TRS) released were determined using the DNS method (Ghose, 1987) and the glucose available was estimated by GOD-POD test kit. The hydrolysis yield were calculated for reducing sugars and glucose using Equations 1 and 2, respectively (Dowe and Mcmillan, 2001; Selig et al., 2008), in order to verify the synergistic actions of cellulases and $\beta$-glucosidase about delignified mature coconut fibre.

$$
\begin{aligned}
& \text { Hydrolysis yield }(\%)=\frac{\text { total reducing sugars }}{\text { polysaccharide in the substrate }} \cdot 100 \\
& \text { Hydrolysis yield }(\%)=\frac{\text { glucose }}{1,111 \mathrm{f} . \text { biomass }} \cdot 100
\end{aligned}
$$

where:

total reducing sugars = reducing sugars concentration $(\mathrm{g} / \mathrm{L})$; glucose $=$ glucose concentration $(\mathrm{g} / \mathrm{L})$;

polysaccharide in the substrate $=$ polysaccharide concentration $(\mathrm{g} / \mathrm{L})$;

biomass = concentration of dry biomass initial in the enzymatic hydrolysis $(\mathrm{g} / \mathrm{L})$;

$\mathrm{f}=$ constitutes of cellulose fraction of dry biomass ( $\mathrm{g}$ cellulose/g dry biomass);

$1.111=$ consists in the conversion factor of cellulose to glucose equivalent.

\section{Experimental design of enzymatic hydrolysis}

In order to relate the influence of the independent variables of enzymes from $L$. ramosa (X1, mL) and enzymes from $T$. reesei (X2, FPU) on the dependent variable reducing sugars (reducing sugar, \%) and glucose (glucose, \%), a 23 central composite experimental design (CCD) was used, as shown in the Table 2.

The mathematical model (Equation 3) corresponding to the experimental design for reducing sugars and glucose is given in the form:

$Y_{i}=\beta_{0}+\beta_{1} X_{1}+\beta_{2} X_{2}+\beta_{11}+\beta_{22}+\beta_{12} X_{1} X_{2}$

where:

$\mathrm{Yi}=$ response function;

$\mathrm{X} 1, \mathrm{X} 2=$ values of the independent variables;

$\beta 0=$ coefficient relating the interception of the plane with the axis of response; $\beta 1, \beta 2=$ linear coefficients estimated by method of the least squares;

$\beta 11, \beta 22=$ coefficient of the quadratic variables;

$\beta 12=$ coefficient of interaction between the independent variables.

The quality of the fit of the polynomial model equation was evaluated by the coefficient of determination $\mathrm{R}^{2}$ and the statistical significance was evaluated by Fisher's F-test for analysis of variance (ANOVA) with a 95\% confidence level. The effect of each independent variable and also their interaction effects were determined. ANOVA results generated the Pareto charts of interactions and effects. The experimental design package Statistica (Statsoft®, USA) was the software used for data analysis.

\section{Bioethanol production}

\section{Microorganism}

The microorganism $S$. cerevisiae was used for bioethanol production. $S$. cerevisiae $\mathrm{PE} 2$ strain was obtained from the Fementec Ltda Company (São Paulo, Brazil). Microorganisms were stored in (1) inclined culture medium immersed in mineral oil, (2) skim milk medium and (3) lyophilized.

\section{Inoculum preparation}

S. cerevisiae was maintained in Petri dishes containing PDA culture medium at $30^{\circ} \mathrm{C}$, during $24 \mathrm{~h}$. Strain for inoculation was grown in $250 \mathrm{~mL}$ Erlenmeyer flask with $100 \mathrm{~mL}$ of sterile culture medium containing $50 \mathrm{~g} / \mathrm{L}$ glucose, $1 \mathrm{~g} / \mathrm{L}$ ammonium sulfate, $0.5 \mathrm{~g} / \mathrm{L}$ potassium phosphate, $0.25 \mathrm{~g} / \mathrm{L}$ magnesium sulfate, $10 \mathrm{~g} / \mathrm{L}$ yeast extract, $10 \mathrm{~g} / \mathrm{L}$ peptone at $30{ }^{\circ} \mathrm{C}$ and $200 \mathrm{rpm}$ in an orbital shaker, during $12 \mathrm{~h}$ (Santos et al., 2010). Cell concentration was inoculated to an equivalent optical density of 2.0 at $600 \mathrm{~nm}$ in a spectrophotometer UV-VIS (de Souza et al., 2012).

\section{Semi-simultaneous saccharification and fermentation (SSSF)}

Semi-simultaneous saccharification and fermentation was carried out during $12 \mathrm{~h}$ of presaccharification $+36 \mathrm{~h}$ of SSF process using mature coconut fibre pretreated by Alk$\mathrm{H}_{2} \mathrm{O}_{2} / \mathrm{NaOH}$ as substrate. SSSF was performed with $2 \%(\mathrm{w} / \mathrm{v})$ of delignified pretreated solids in 48 $\mathrm{mL}$ of sodium citrate buffer $50 \mathrm{mM}(\mathrm{pH}=5.0)$, enzymatic load of $24 \mathrm{~mL}$ of crude enzyme extract from $L$. ramosa and 25 FPU of enzymes from $T$. reesei per $2 \mathrm{~g}$ of delignified pretreated solid (see 
experiment 6 in the Table 1), selected in stage of enzymatic hydrolysis. In this presaccharification period, the medium temperature was maintained at $50{ }^{\circ} \mathrm{C}$. After $12 \mathrm{~h}$ of presaccharification, the medium temperature was adjusted to $30{ }^{\circ} \mathrm{C}$ and supplemented with $1 \mathrm{~g} / \mathrm{L}$ ammonium sulfate, 0.5 $\mathrm{g} / \mathrm{L}$ potassium phosphate, $0.25 \mathrm{~g} / \mathrm{L}$ magnesium sulfate, $2 \mathrm{~g} / \mathrm{L}$ yeast extract and $1 \mathrm{~g} / \mathrm{L}$ peptone. Then, the fermentative process was started by adding the strain, in an orbital shaker at $200 \mathrm{rpm}$. The samples were taken at $0,6,12,24,36$ and $48 \mathrm{~h}$. Concentrations of ethanol and sugars were determined by high performance liquid chromatography (HPLC) (see Analysis of samples in high performance liquid chromatography Section). All determinations were performed in duplicate. The ethanol yield (Equation 4) was calculated assuming that all the potential glucose in the pretreated delignified solids was available for fermentation and that $1 \mathrm{~g}$ of glucose yielded 0.511 $\mathrm{g}$ of ethanol and $1 \mathrm{~g}$ of cellulose gave $0.9 \mathrm{~g}$ of glucose (modified of Dowe and McMillan, 2001).

Ethanol yield $(\%)=\frac{\text { ethanol }}{\text { glucose initial } .0 .511} \cdot 100$

where:

ethanol $=$ final ethanol concentration $(\mathrm{g} / \mathrm{L})$; glucose initial $=$ initial glucose concentration $(\mathrm{g} / \mathrm{L})$; $0.511=$ consists of the conversion factor of glucose to ethanol.

\section{Analysis of samples in high performance liquid chromatography (HPLC)}

All the samples were centrifuged, filtered through a $0.2 \mu \mathrm{m}$ sterile membrane filter and used for analyses of glucose, xylose and ethanol. Chromatographic separation was performed using a Shim-pack SCR-101H column (Shimadzu, Japan) and mobile phase $0.005 \mathrm{~mol} / \mathrm{L}$ sulfuric acid, flow of $0.6 \mathrm{~mL} \cdot \mathrm{min}^{-1}$ and column temperature $65{ }^{\circ} \mathrm{C}$ using a Shimadzu chromatograph (Shimadzu, Japan) equipped with refraction-index detector (Shimadzu, Japan).

\section{RESULTS AND DISCUSSION}

\section{Analysis of the synergistic effects}

The initial enzyme activities of enzymes from $T$. reese $i$ were $70 \mathrm{FPU} / \mathrm{mL}$ of cellulase, $0.3 \mathrm{CBU} / \mathrm{mL}$ of $\beta$-glucosidase and $216 \mathrm{IU} / \mathrm{mL}$ of xylanase. The initial enzyme activities of crude enzyme extract from $L$. ramosa were $0.08 \mathrm{FPU} / \mathrm{mL}$ of cellulase, 3.7 $\mathrm{CBU} / \mathrm{mL}$ of $\beta$-glucosidase and $2.41 \mathrm{IU} / \mathrm{mL}$ of xylanase.

Mature coconut fibre pretreated by Alk$\mathrm{H}_{2} \mathrm{O}_{2} / \mathrm{NaOH}$ (biomass composition: $52.25 \pm 0.60$ of cellulose; $25.93 \pm 0.46$ of hemicellulose; $8.71 \pm$ 0.15 of insoluble lignin; $0.10 \pm 0.02$ of soluble lignin; $0.07 \pm 0.03$ of extractable; $3.08 \pm 0.12$ of ash) was submitted to enzymatic hydrolysis using an experimental design with different concentrations of enzymes from $T$. reese $i$ and crude enzyme extract from L. ramosa (see Table 1), resulted in the conversions and yields of delignified mature coconut fibre into reducing sugars between $12.7-82.14 \%$ and $0.09-0.64 \mathrm{~g}$ reducing sugars/g dry biomass, respectively (Figure $1 \mathrm{~A}-\mathrm{B}$ ). Initial hydrolysis rate at $12 \mathrm{~h}$ between $0.10-0.89 \mathrm{~g} /(\mathrm{L} . \mathrm{h})$ (Figure 1C). Conversions and yields of delignified mature coconut fibre into glucose ranged between $10.16-83.78 \%$ and $0.06-0.43$ g glucose/g dry biomass, respectively (Figure 2A-B). Initial hydrolysis rate at $12 \mathrm{~h}$ were found between 0.03 $0.35 \mathrm{~g} /$ (L.h) (Figure 2C).

Table 1 - Experimental design of the mixture of crude enzyme extract from L. ramosa and enzymes from $T$. reesei used in the hydrolysis of mature coconut fibre pretreated by $\mathrm{Alk}-\mathrm{H}_{2} \mathrm{O}_{2} / \mathrm{NaOH}$. Besides conversion of mature coconut fibre pretreated into total reducing sugars and glucose.

\begin{tabular}{c|c|c|c|c|c|c}
\hline \multirow{3}{*}{ Experiment } & \multicolumn{4}{c|}{ Conditions } & \multicolumn{2}{c}{ Results } \\
\cline { 2 - 7 } & \multicolumn{2}{|c|}{ Codified variable } & \multicolumn{2}{c}{ Real value } & \multicolumn{2}{c}{ Conversions (\%) } \\
\cline { 2 - 7 } & $\begin{array}{c}\text { Enzymes of } \\
\text { L. } \text { ramosa } \boldsymbol{a}\end{array}$ & $\begin{array}{c}\text { Enzymes of } \\
\boldsymbol{T} \text {. reesei }\end{array}$ & $\begin{array}{c}\text { Enzymes of } \boldsymbol{L} \text {. } \\
\text { ramosa }(\mathbf{m L})\end{array}$ & $\begin{array}{c}\text { Enzymes of } \boldsymbol{T} . \\
\text { reesei }(\mathbf{F P U})\end{array}$ & $\begin{array}{c}\text { Reducing } \\
\text { sugars }\end{array}$ & Glucose \\
\hline 1 & -1 & 0 & 0 & 12.5 & $37.79 \pm 0.99$ & $10.16 \pm 0.35$ \\
2 & 0 & -1 & 24 & 0 & $12.07 \pm 0.34$ & $12.04 \pm 0.39$ \\
3 & 1 & -1 & 48 & 0 & $13.78 \pm 0.37$ & $13.25 \pm 0.41$ \\
4 & 0 & 0 & 24 & 12.5 & $68.12 \pm 0.87$ & $57.07 \pm 0.97$ \\
5 & -1 & 1 & 0 & 25 & $44.55 \pm 1.35$ & $27.78 \pm 0.24$ \\
6 & 0 & 1 & 24 & 25 & $76.58 \pm 0.34$ & $60.71 \pm 0.92$ \\
7 & 1 & 0 & 48 & 12.5 & $68.17 \pm 0.44$ & $69.28 \pm 0.72$ \\
8 & 0 & 0 & 24 & 12.5 & $66.43 \pm 0.50$ & $58.17 \pm 0.62$ \\
9 & 1 & 1 & 48 & 25 & $82.14 \pm 0.67$ & $83.78 \pm 1.00$ \\
\hline
\end{tabular}



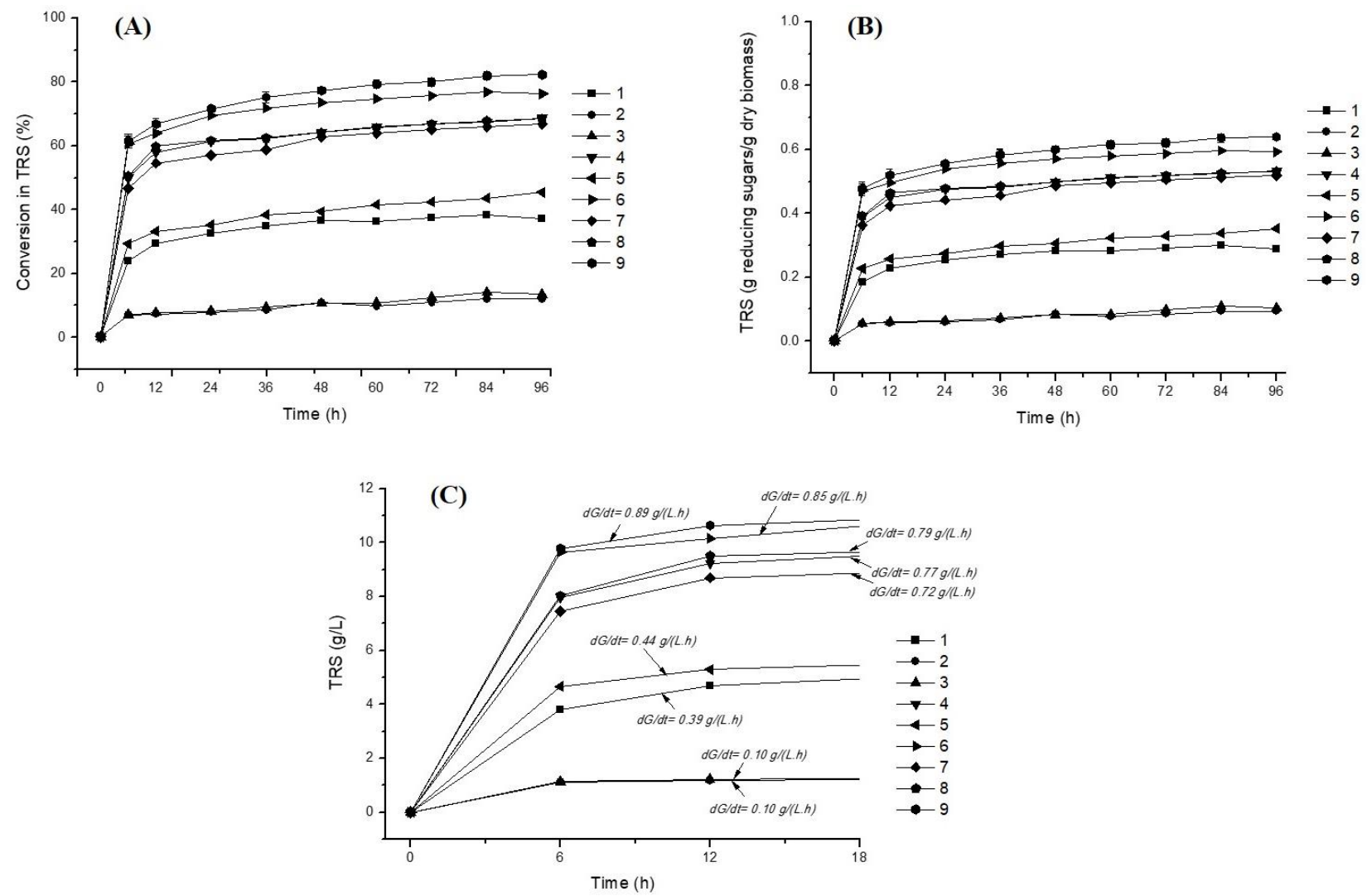

Figure 1 - Enzymatic hydrolysis of mature coconut fibre pretreated by Alk- $\mathrm{H}_{2} \mathrm{O}_{2} / \mathrm{NaOH}$. A) Conversion of mature coconut fibre pretreated in total reducing sugars (TRS) (\%); B) Digestibility of mature coconut fibre pretreated in TRS (g reducing sugars/g dry biomass); C) Initial hydrolysis rate at $12 \mathrm{~h}$ of mature coconut fibre pretreated. Symbol 1 to 9 in accordance with the experimental design (Table 1), being Experiment 1: enzymes of $L$. ramosa $(0 \mathrm{~mL})$ and enzymes of $T$. reesei $(12.5 \mathrm{FPU})$; Experiment 2: enzymes of $L$. ramosa $(24 \mathrm{~mL})$ and enzymes of T. reesei (0 FPU); Experiment 3: enzymes of L. ramosa $(48 \mathrm{~mL})$ and enzymes of $T$. reesei (0 FPU); Experiment 4: enzymes of $L$. ramosa $(24 \mathrm{~mL})$ and enzymes of $T$. reesei $(12.5 \mathrm{FPU})$; Experiment 5: enzymes of $L$. ramosa $(0 \mathrm{~mL})$ and enzymes of T. reesei $(12.5 \mathrm{FPU})$; Experiment 6: enzymes of L. ramosa $(24 \mathrm{~mL})$ and enzymes of T. reesei (25 FPU); Experiment 7: enzymes of L. ramosa $(48 \mathrm{~mL})$ and enzymes of T. reesei $(12.5$ FPU); Experiment 8: enzymes of L. ramosa $(24 \mathrm{~mL})$ and enzymes of T. reesei (12.5 FPU); Experiment 9: enzymes of $L$. ramosa ( $48 \mathrm{~mL}$ ) and enzymes of $T$. reesei (25 FPU).

The optimal point for enzyme mixture was enzymatic load of $24 \mathrm{~mL}$ of the crude enzyme extract from L. ramosa and 25 FPU enzymes from T. reesei per $2 \mathrm{~g}$ of delignified mature coconut fibre (see Table 1, experiment 6 ). The results obtained showed the synergistic effects between enzymes from $T$. reesei and crude enzyme extract from L. ramosa. These results corroborate with the results found by Gonçalves et al. (2013c) and Gonçalves et al. (2014) using commercial enzymes (30 FPU, 75 CBU and 130 IU xylanase per g of solid) and mature coconut fibre submitted to the hydrothermic pretreatment catalysed with sodium hydroxide reached conversion into glucose of $84.49 \%$ (Gonçalves et al., 2013c). Mature coconut fibre pretreated by Alk- $\mathrm{H}_{2} \mathrm{O}_{2} / \mathrm{NaOH}$ resulted in conversion into glucose of $76.21 \%$ (Gonçalves et al., 2014).
Thus, the results obtained in this work can evidence the potential of this enzymatic cocktail.

Furthermore, the individual analysis of the experiments showed crude enzyme extract from $L$. ramosa enabled lower conversions of reducing sugars and glucose (see Table 1, experiments 1 and 5) derived from hydrolysis of cellulose and hemicellulose. This low concentration of $\beta$-glucosidase suggests an accumulation of cellobiose, inhibiting endoglucanase and cellobiohydrolase, consequently produces inhibition and repression of the final product during hydrolysis (Singhand Bishnoi, 2012; Gupta and Lee, 2013; Singhania et al., 2013; Zimbardi et al., 2013; Garcia et al., 2018). That way, the ratio of $\beta$-glucosidase is low, like in the commercial enzyme preparations of $T$. reesei (Wang et al., 2013), promoting lower yield of 
delignified mature coconut fibre into fermentable sugars. Furthermore, significant differences between conversion of delignified mature coconut

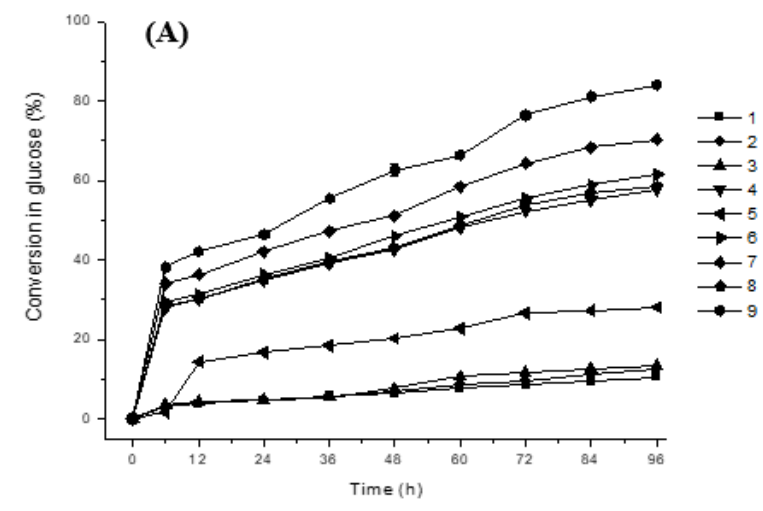

fibre into reducing sugars and to glucose, possibly reflect the action of the xylanases in the solid, generating xylose.

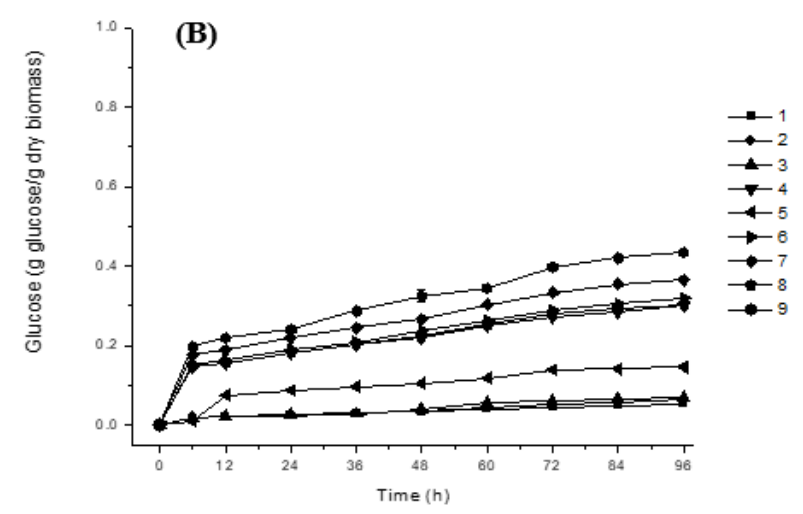

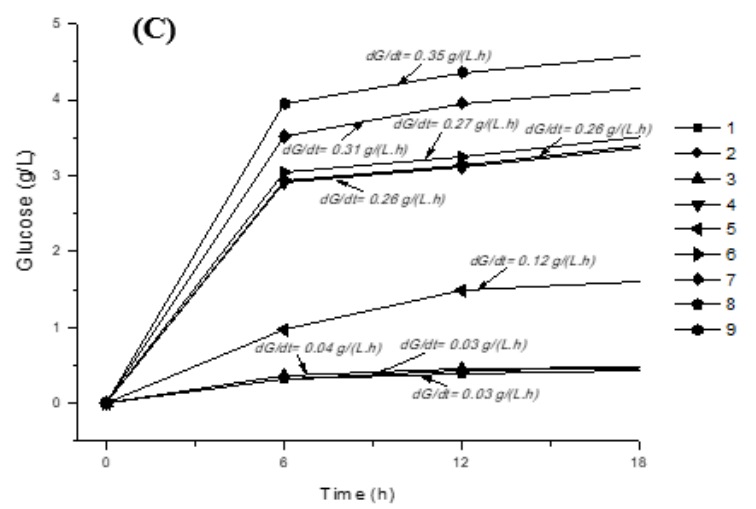

Figure 2 - Enzymatic hydrolysis of mature coconut fibre pretreated by Alk- $\mathrm{H}_{2} \mathrm{O}_{2} / \mathrm{NaOH}$. A) Conversion of mature coconut fibre pretreated in glucose (\%); B) Digestibility of mature coconut fibre pretreated in glucose (g glucose/g dry biomass); C) Initial hydrolysis rate at $12 \mathrm{~h}$ of mature coconut fibre pretreated. Symbol 1 to 9 in accordance with the experimental design (Table 1), being Experiment 1: enzymes of L. ramosa $(0 \mathrm{~mL})$ and enzymes of T. reesei (12.5 FPU); Experiment 2: enzymes of L. ramosa $(24 \mathrm{~mL})$ and enzymes of $T$. reesei $(0$ FPU); Experiment 3: enzymes of $L$. ramosa $(48 \mathrm{~mL})$ and enzymes of $T$. reesei (0 FPU); Experiment 4: enzymes of $L$. ramosa $(24 \mathrm{~mL})$ and enzymes of $T$. reesei (12.5 FPU); Experiment 5: enzymes of $L$. ramosa $(0 \mathrm{~mL})$ and enzymes of T. reesei (12.5 FPU); Experiment 6: enzymes of L. ramosa $(24 \mathrm{~mL})$ and enzymes of $T$. reesei $(25$ FPU); Experiment 7: enzymes of $L$. ramosa $(48 \mathrm{~mL})$ and enzymes of $T$. reesei (12.5 FPU); Experiment 8: enzymes of $L$. ramosa $(24 \mathrm{~mL})$ and enzymes of T. reesei (12.5 FPU); Experiment 9: enzymes of L. ramosa (48 $\mathrm{mL}$ ) and enzymes of $T$. reesei (25 FPU)

The effects of the absence of enzymes from $T$. reesei have resulted in smaller conversions of delignified mature coconut fibre into reducing sugars and glucose (see Table 1, experiments 2 and 3 ), reflecting its low levels of cellulases. Therefore, inefficient hydrolysis of cellulose results in the low amount of cellobiose released and, consequently, low amount of glucose released by $\beta$-glucosidases.

However, when analysing the presence of both enzymes in the delignified mature coconut fibre, it was observed a significant increase in the conversion into reducing sugars and glucose (see Table 1, experiments 4-9). These facts demonstrate the need for cellulases and $\beta$-glucosidase during enzymatic hydrolysis. Besides these results confirmed the importance of $\beta$-glucosidase in this process as already reported by Gupta and Lee (2013), Singhania et al. (2013), Wang et al. (2013), Rana et al. (2014) and Garcia et al. (2018). Thus, the synergy between $\beta$-glucosidase and cellulases improves enzymatic hydrolysis yield of lignocellulosic materials (Berlin et al., 2007; Singh and Bishnoi, 2012).

In addition, Zimbardi et al. (2013) carried out the hydrolysis using Colletotrichum graminicola extract resulting in maximal yields of $11.3 \%$ for reducing sugars and $4.4 \%$ for glucose, in $72 \mathrm{~h}$. Yields obtained using T. reesei extract, achieved $18.3 \%$ for reducing sugars and $18.7 \%$ for glucose. However, when using a mixture of both extracts, a synergic effect was observed and yields of $24.6 \%$ for 
reducing sugars and $25.5 \%$ for glucose were attained in $24 \mathrm{~h}$. Moreover, maximal yields reached $37.6 \%$ of reducing sugars and $33.1 \%$ of glucose in $48 \mathrm{~h}$. Pandit et al. (2013) have reported the cellulases production using wheat straw as substrate and subsequent hydrolysis, resulting in yield greater than $72 \%$ of reducing sugars. Roslan et al. (2011) carried out pretreatment of rice straw by few cycles of wet disc milling prior saccharification using the crude cellulase produced by Aspergillus $s p$., obtaining a hydrolysis yield of $90 \%$. Saini et al. (2013) have reported the enzymatic hydrolysis of sweet sorghum bagasse using indigenously-produced cellulases from a novel fungal consortium of A. flavus
F-80 and A. niger MTCC-2425, showing a maximum hydrolysis yield of $51.21 \%$. Rana et al. (2014) using cellulases from $T$. reesei RUT-C30 and $\beta$ glucosidase from $A$. saccharolyticus in the hydrolysis of wet-exploded corn stover and wet-exploded loblolly pine obtained glucose yields of $81 \%$ and $55 \%$, respectively. These results reported by Zimbardi et al. (2013), Pandit et al. (2013), Roslan et al. (2011), Saini et al. (2013) and Rana et al. (2014) were compared to the results obtained in this work, showing the synergistic mixture between enzymes from $T$. reesei and crude enzyme extract from $L$. ramosa were efficient.

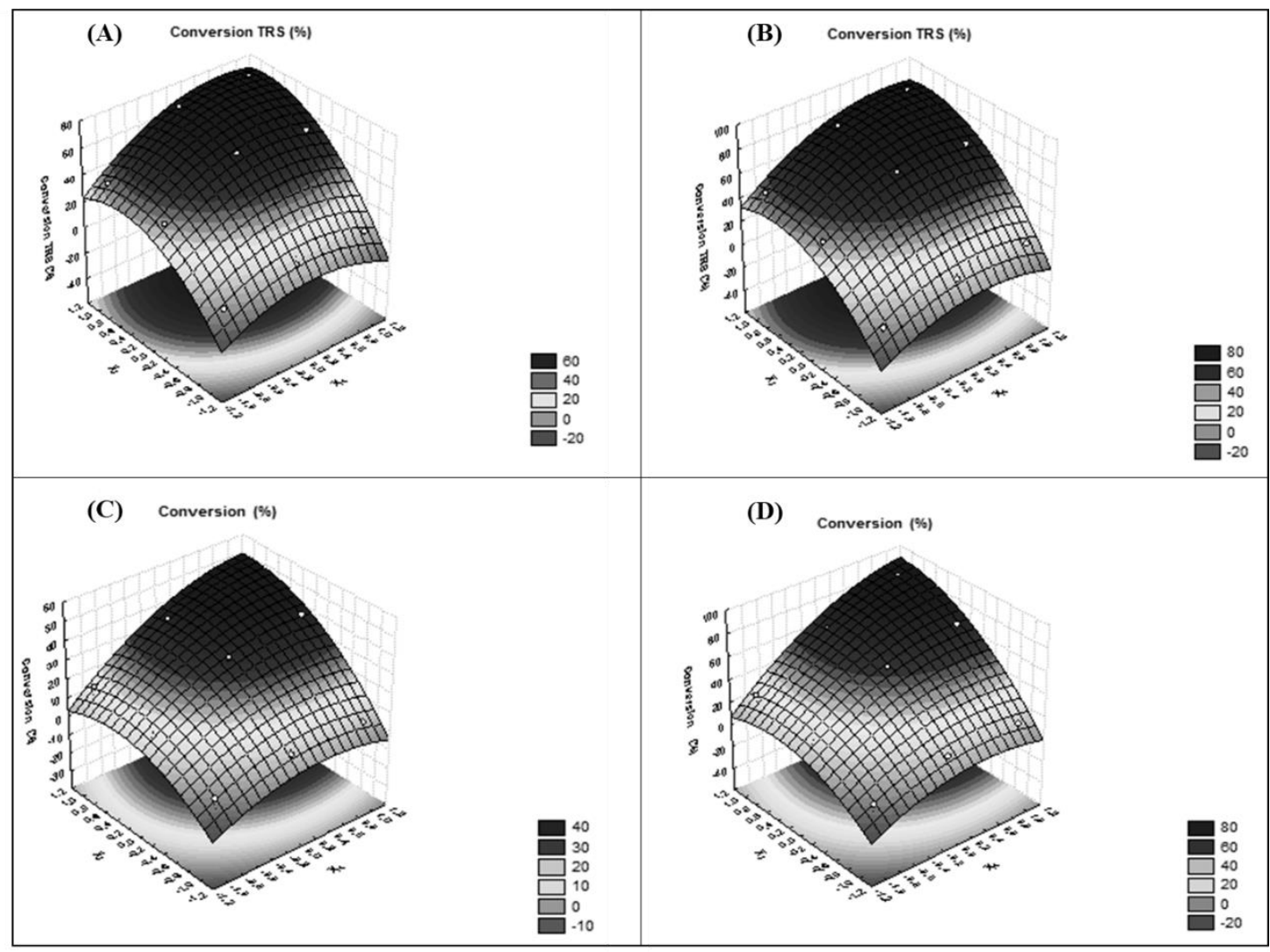

Figure 3 - Response surface and contour plot of mature coconut fibre pretreated by $\mathrm{Alk}-\mathrm{H}_{2} \mathrm{O}_{2} / \mathrm{NaOH}$ converted into TRS and glucose (\%). A) TRS variation in function of enzymes in $24 \mathrm{~h}$. B) TRS variation in function of enzymes in $96 \mathrm{~h}$. C) Glucose variation in function of enzymes in $24 \mathrm{~h}$. D) Glucose variation in function of enzymes in $96 \mathrm{~h}$.

\section{Experimental design and statistical analysis of the effects of cellulase and $\beta$-glucosidase in the hydrolysis of mature coconut fibre pretreated by Alk- $\mathrm{H}_{2} \mathrm{O}_{2} / \mathrm{NaOH}$}

Optimization of hydrolysis process is one of the most important stages in the development of an efficient strategy as well as cost effective bioethanol fermentation process. Response surface methodology (RSM) is an effective optimization tool wherein many factors and interactions affecting the response can be identified with fewer experimental trials (Saini et al., 2013; Sindhu et al., 2014). The amount of protein components may greatly be decreased in a minimal, synthetic set of enzymes by optimizing the ratios of the necessary enzymes and by omitting unnecessary proteins (Wang et al., 2013). Singh and Bishnoi (2012) have reported the RSM using wheat straw pretreated by microwave alkali and enzyme production by A. flavus and $T$. 
reesei, resulting in the yield into glucose of $82 \%$. Similar results were obtained in this work (Figure 3A-D) allowing optimization of enzymatic hydrolysis process, with optimal point for enzyme mixture with an enzymatic load of $24 \mathrm{~mL}$ for crude enzyme extract from L. ramosa and 25 FPU enzymes from T. reesei per $2 \mathrm{~g}$ of delignified mature coconut fibre

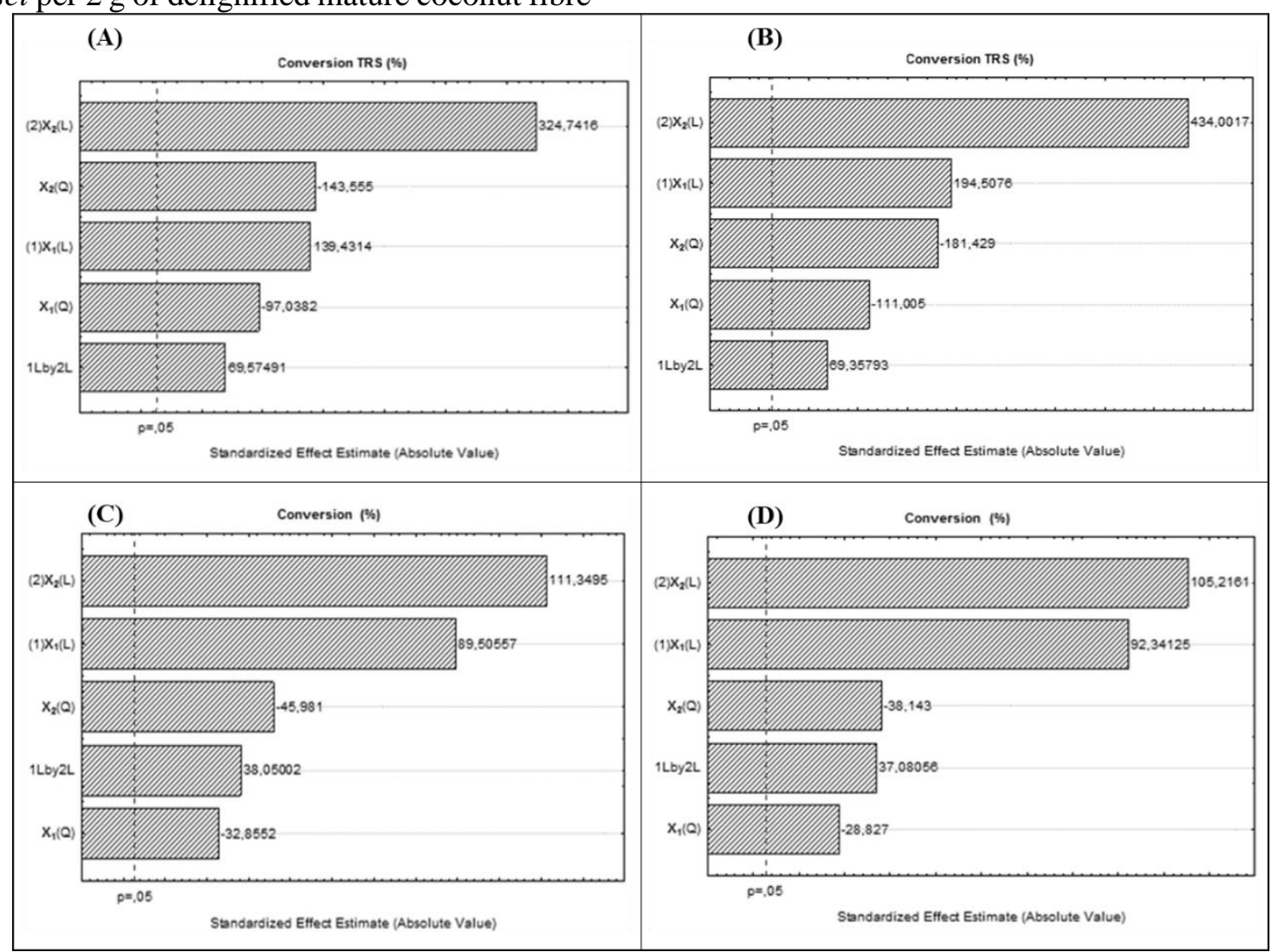

Figure 4 - Pareto charts for standardized effects of enzymes in mature coconut fibre pretreated by Alk$\mathrm{H}_{2} \mathrm{O}_{2} / \mathrm{NaOH}$. A) Conversion of mature coconut fibre pretreated into TRS in $24 \mathrm{~h}$; B) Conversion of mature coconut fibre pretreated into TRS in $96 \mathrm{~h}$; C) Conversion of mature coconut fibre pretreated into glucose in 24 $\mathrm{h}$; D) Conversion of mature coconut fibre pretreated into glucose in $96 \mathrm{~h}$.

According to ANOVA results for reducing sugars and glucose yields as function of crude enzyme extract from $L$. ramosa and enzymes from $T$. reesei in the delignified mature coconut fibre, the linear term for $\mathrm{X}_{1}, \mathrm{X}_{2}$, quadratic for $X_{1}, X_{2}$ and the interaction $X_{1} X_{2}$ have a significant effect on reducing sugars and glucose yields responses with $p$-value under a significance level of $\alpha=0.05$. These effects can be visualized in the standardized Pareto charts (Figure 4A-D) and ANOVA (Table 2A-B). Observe that the variables for crude enzyme extract from $L$. ramosa, enzymes from $T$. reese $i$ and crude enzyme extract from L. ramosa as well as from $T$. reesei interaction are important in a confidence level of $95 \%$ for the reducing sugars and glucose yields (Figure 4A-D and Table 2A-B). The effects of enzymes are (see Table 1, experiment 6), resulting in the yield into reducing sugars and glucose of $76.58 \%$ and $60.71 \%$, in that order. Besides of Pareto charts show the importance of mixing between the enzymes from $T$. reesei and crude enzyme extract from L. ramosa (Figure 4A-D).

positive, meaning that the higher the independent variables the higher the dependent ones (Figure 3A-D).

Multiple regression analysis and ANOVA of the experimental data were performed for the mathematical model fitting. The models in terms of codified values (see Table 2) expressed in Equations 5-8 represent the reducing sugars and glucose from delignified mature coconut fibre, in function of crude enzyme extract from $L$. ramosa $\left(\mathrm{X}_{1}\right)$ and enzymes from $T$. reesei $\left(\mathrm{X}_{2}\right)$.

Sugar $=$ Reducing sugars in $24 \mathrm{~h}=59.61+$

$$
\begin{gathered}
11.48 * X_{1}+23.73 * X_{2}-12.81 *-19.95 *+ \\
7.01 * X_{1} X_{2}\left(R^{2}=0.989 ; R_{\text {adj }}^{2}=0.975\right)
\end{gathered}
$$


Sugar $=$ Reducing sugars in $96 \mathrm{~h}=66.38+$ $13.34 * X_{1}+29.77 * X_{2}-12.21 *-19.95 *+$ $5.83 * \mathrm{X}_{1} \mathrm{X}_{2}\left(R^{2}=0.993 ; R_{\text {adj }}^{2}=0.984\right)$

Sugar $=$ Glucose in $24 \mathrm{~h}=32.73+12.01 * \mathrm{X}_{1}$ $+14.94 * X_{2}-7.07 *-9.89 *+6.25 * X_{1} X_{2}\left(R^{2}=\right.$

$$
\left.0.940 ; R_{\text {adj }}^{2}=0.926\right)
$$

Sugar $=$ Glucose in $96 \mathrm{~h}=54.64+21.55^{*} \mathrm{X}_{1}$ $+24.56 * \mathrm{X}_{2}-10.79 *-14.27 *+10.60 * \mathrm{X}_{1} \mathrm{X}_{2}$ $\left(R^{2}=0.963 ; R^{2}\right.$ adj $\left.=0.938\right)$

Table 2 - Analysis of variance in the hydrolysis of mature coconut fibre pretreated by $A l k-\mathrm{H}_{2} \mathrm{O}_{2} / \mathrm{NaOH}$ converted into sugars in function of crude enzyme extract from $L$. ramosa (x1) and enzymes from $T$. reesei (x2). A) Total reducing sugars (TRS); B) Glucose.

\begin{tabular}{llllll} 
A Source & Sum of Squares & d.f. & Mean Square & $\boldsymbol{F}$-value & $\boldsymbol{p}$-value \\
\hline$x_{1}{ }^{2}$ & 805.81 & 1 & 805.81 & 199.14 & $0.001 *$ \\
$x_{1}$ & 376.33 & 1 & 376.33 & 93.0 & $0.002 *$ \\
$x_{2}$ & 3344.54 & 1 & 3344.54 & 826.54 & $0.002 *$ \\
$x_{2}{ }^{2}$ & 906.22 & 1 & 906.22 & 223.96 & $0.001 *$ \\
$x_{1} x_{2}$ & 110.03 & 1 & 110.03 & 28.73 & $0.019 *$ \\
Residual Error & 12.14 & 3 & 4.05 & & \\
Lack of Fit & 12.14 & 2 & 6.07 & 5375.27 & $0.01 *$ \\
Pure Error & 0.20 & 1 & 0.20 & & \\
Total & 5567.21 & 8 & & & \\
\hline
\end{tabular}

d.f., degree of freedom;

* significant;

Fcalculated: 261.42;

Ftabular: 6.26.

B

\begin{tabular}{llllll}
\hline Source & Sum of Squares & d.f. & Mean Square & $\boldsymbol{F}$-value & $\boldsymbol{p}$-value \\
\hline$x_{1}$ & 2256.80 & 1 & 2256.80 & 53.85 & $0.005 *$ \\
$x_{1}{ }^{2}$ & 410.14 & 1 & 410.14 & 9.79 & $0.042 *$ \\
$x_{2}$ & 2822.81 & 1 & 2822.81 & 67.36 & $0.004 *$ \\
$x_{2}{ }^{2}$ & 617.57 & 1 & 617.57 & 14.74 & $0.031 *$ \\
$x_{1} x_{2}$ & 214.63 & 1 & 211.87 & 9.52 & $0.042 *$ \\
Residual Error & 125.72 & 3 & 41.91 & & \\
Lack of Fit & 125.12 & 2 & 62.56 & 104.41 & 0.069 \\
Pure Error & 0.60 & 1 & 0.60 & & \\
Total & 6572.79 & 8 & & & \\
\hline
\end{tabular}

d.f., degree of freedom;

* significant;

Fcalculated: 30.33;

Ftabular: 6.26.

Response surfaces were drawn as three-dimensional plots of the second-order polynomial models (Equations 5-8) as a function of the two most strongly influencing variables. Reducing sugars and glucose yields were plotted in function of crude enzyme extract from $L$. ramosa and enzymes from T. reesei (see Figure 3A-D) and demonstrate that the increase in the reducing sugars and glucose yields are correlated with increases of crude enzyme extract from $L$. ramosa and enzymes from $T$. reesei in theexperiments (see Table 1).
Results of ANOVA listed in the Equations 5-8 revealed that the second-order polynomial models adequately represent the responses of sugars yield with coefficients of determination $R^{2}$, which indicates that $98.9 \%, 99.3 \%, 94.0 \%$ and $96.3 \%$ of the variability of response might be explained by the model. These values are in accordance with the adjusted coefficient of determination $R^{2}$ adj $=0.975$, $0.984,0.926$ and 0.938 .

An efficient hydrolysis of lignocellulosic materials into soluble sugars for biofuel production 
necessitates of the synergistic interaction of multiple enzymes (Zhou et al., 2009; Billard et al., 2012; Rana et al., 2014). Formulation of individual hydrolytic enzyme activities in an overall system can reduce total enzyme loadings and costs in a cellulosic ethanol production (Gupta and Lee, 2013; Wang et al., 2013; Rana et al., 2014). This way, a significant influence on bioconversion process in cost reduction of pretreatment and enzymatic hydrolysis is very important for influence bioethanol commercialization (Fang et al., 2010; Wang et al., 2013, Gonçalves et al., 2015). Therefore, the results obtained in this work allow to optimize the enzymatic load (crude enzyme extract from L. ramosa and enzymes from $T$. reesei) used in the hydrolysis of delignified mature coconut fibre.

In addition, enzyme should be produced in situ and used in crude form to reduce the cost (Fang et al., 2009; Gonçalves et al., 2013a). Thus, some works showed that wheat bran is a good carbon source for the cellulases production as well as hemicellulases by different fungi in SSB, even in the absence of any supplementary carbon and nitrogen source, as evidenced by Zimbardi et al. (2013) and Gonçalves et al. (2013a). In this work, enzymes were produced using as substrate the wheat bran, with subsequent use of this crude enzyme extract in the enzymatic hydrolysis. Thus, the crude enzyme extract did not provide negative effect on enzymatic hydrolysis and SSSF (see Fermentation process for bioethanol production Section), motivated by the residual compounds from SSB (secondary metabolites of the L. ramosa and residues of wheat bran).

The strategy of SSSF was carried out using $S$. cerevisiae $\mathrm{PE} 2$, mature coconut fibre pretreated by Alk- $\mathrm{H}_{2} \mathrm{O}_{2} / \mathrm{NaOH}$, optimized enzymatic load of 24 $\mathrm{mL}$ crude enzyme extract from L. ramosa and 25 FPU enzymes from $T$. reesei per $2 \mathrm{~g}$ of solid (see Table 1, experiment 6). According to Shen and Agblevor (2010), the performance of fermentative strategy can be assessed by two indicators: conversion yield (g ethanol/g glucose) and volumetric productivity of ethanol g/(L.h).

The results of this work indicate that glucose from enzymatic hydrolysis of delignified mature coconut fibre could be fermented into ethanol by $S$. cerevisiae and the kinetic profile showed increases in the availability of glucose during the initial $12 \mathrm{~h}$, with a gradual decrease of glucose after inoculation (Figure 5). Bioethanol production by the S. cerevisiae resulted in the production, yield and volumetric productivity of ethanol were $4.62 \mathrm{~g} / \mathrm{L}, 0.41$ $\mathrm{g}$ ethanol/g glucose $(80.41 \%$ of value of theoretical ethanol) and $0.13 \mathrm{~g} /(\mathrm{L} . \mathrm{h})$, in that order, in $36 \mathrm{~h}$ of SSSF. Therefore, showing the absence of inhibitors contained in the crude enzyme extract from $L$. ramosa used in the SSSF. Furthermore, Gonçalves et al. (2013c) carried out the SSSF using mature coconut fibre hydrothermally pretreated with sodium hydroxide, using commercial enzymes and $S$. cerevisiae PE2, obtaining for production, yield and productivity of ethanol values such as $26.18 \mathrm{~g} / \mathrm{L}$, $0.46 \mathrm{~g}$ ethanol/g glucose, $0.44 \mathrm{~g} /(\mathrm{L} . \mathrm{h})$, respectively. Singh and Bishnoi (2012) carried out microwave alkali pretreatment in wheat straw and used enzymes produced by $A$. flavus and $T$. reesei. The concentrated enzymatic hydrolyzate was fermented for bioethanol production by S. cerevisiae, Pichia stipitis and co-culture of both. The ethanol yields were $0.48 \mathrm{~g}$ ethanol/g glucose, $0.43 \mathrm{~g}$ ethanol/g glucose and $0.40 \mathrm{~g}$ ethanol $/ \mathrm{g}$ glucose, in that order. Roslan et al. (2011) carried out bioethanol production of rice straw pretreated by few cycles of wet disc milling prior saccharification. The crude cellulose was produced by Aspergillus sp. and fermentation was carried out by $S$. cerevisiae, resulting in $62.61 \%$ (value of theoretical ethanol). Rocha et al. (2013) carried out bioethanol production by $S$. cerevisiae Y904 using whey and rice byproduct as the substrate and the enzyme complex produced by $A$. niger, resulting $8.4 \mathrm{~g} / \mathrm{L}$ of ethanol. Moreover, Gonçalves et al. (2016) carried out the SSSF using mature coconut fibre pretreated by hydrothermal pretreatment catalysed with sodium hydroxide and commercial enzymes, containing $P$. stipitis or $S$. cerevisiae or Zymomonas mobilis, obtaining yield of $90.18 \%, 91.17 \%$ and $91.03 \%$, in that order. These results corroborate with the results obtained in this work, evidencing the biotechnological potentials of enzymatic cocktail and fermentative strategy tested.

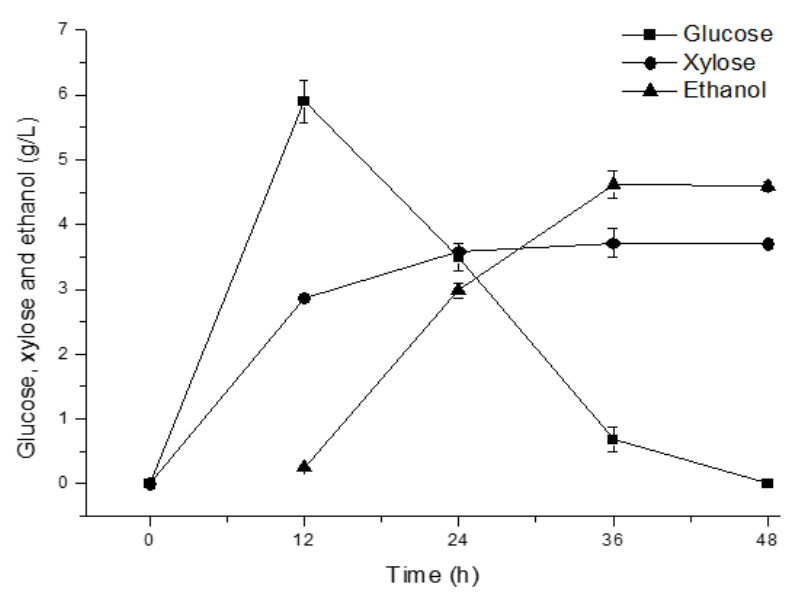

Figure 5 - Fermentation in SSSF by S. cerevisiae using mature coconut fibre pretreated by Alk$\mathrm{H}_{2} \mathrm{O}_{2} / \mathrm{NaOH}$, enzymes from T. reese $i$ and crude enzyme extract from L. ramosa. 


\section{CONCLUSION}

Cellulosic ethanol production face bottlenecks, such as an example the enzymatic hydrolysis step to afford an economic viability of this productive chain. That way, in this work was shown a consistent alternative to alleviate these costs, based in the use of crude enzyme extract from L. ramosa. The mixtures of this extract and enzymes from $T$. reese $i$ allowed significant results for enzymatic hydrolysis of mature coconut fibre pretreated by Alk$\mathrm{H}_{2} \mathrm{O}_{2} / \mathrm{NaOH}$. In addition, indicated absence of inhibitory effects of secondary metabolites from $L$. ramosa contained in the hydrolysed fermented by $S$. cerevisiae. In this sense, allowing to formulate an optimized enzymatic mixed for use in the cellulosic ethanol production. Also highlighted the efficient employments of agro-industrial residues wheat bran and mature coconut fibre - in the enzymes and bioethanol productions.

\section{ACKNOWLEDGMENTS}

The authors gratefully acknowledge the Brazilian research funding agencies $\mathrm{CNPq}$ and CAPES for financial support.

\section{REFERENCES}

Adsul MG, Ghule JE, Shaikh H, Singh R, Bastawde KB, Gokhale D et al. Enzymatic hydrolysis of delignified bagasse polysaccharides. Carbohydrate Polymers, v. 62, p. 6-10, 2005.

Berlin A, Maximenko V, Gilkes N, Saddler J. Optimization of enzyme complexes for lignocellulose hydrolysis. Biotechnology and Bioengineering, v. 97, n. 2, p. 287-296, 2007.

Bibashi E, De-Hoog GS, Pavlidis TE, Symeonidis N, Sakantamis A, Walther G. Wound infection caused by Lichtheimia ramosa due to a car accident. Medical Mycology Case Reports, v. 2, p. 7-10, 2013.

Billard H, Faraj A, Ferreira NL, Menir S, Heiss-Blanquet S. Optimization of a synthetic mixture composed of major Trichoderma reesei enzymes for the hydrolysis of steam-exploded wheat straw. Biotechnology for Biofuels, n. 5, v. 9, p. $1-13,2012$.

Borrás R, Roselló P, Chilet M, Bravo D, Lomas JG, Navarro D. Positive result of the Aspergillus galactomannan antigen assay using bronchoalveolar lavage fluid from a patient with an invasive infection due to Lichtheimia ramosa. Journal of Clinical Microbiology, v. 48, n. 8, p. 3035-3036, 2010.

Carvalheiro F, Duarte LC, Gírio FM. Hemicellulose biorefineries: a review on biomass pretreatments. Journal of Scientific and Industrial Research, v. 67, p. 849-864, 2008.

De Souza CJA, Costa DA, Rodrigues MQRB, dos Santos AF, Lopes MR et al. The influence of presaccharification, fermentation temperature and yeast strain on ethanol production from sugarcane bagasse. Bioresource Technology, v. 109, p. 63-69, 2012.

Dowe N, McMillan J. SSF experimental protocols- lignocellulosic biomass hydrolysis and fermentation. NERL analytical procedure. National Renewable Energy Laboratory. Golden, Colorado, 2001.

Fang H, Zhao C, Song XY. Optimization of enzymatic hydrolysis of steam exploded corn stover by two approaches: response surface methodology or using cellulase from mixed cultures of Trichoderma reesei RUT-C30 and Aspergillus niger NL02. Bioresource Technology, v. 101, p. 4111-4119, 2010.

Fang X, Yano S, Inoue H, Sawayama S. Strain improvement of Acremonium cellulyticus for cellulase production by mutation. Journal of Energy Bioscience, v. 107, p. 256-261, 2009.

FAO (2012) World Production. http://www.faostat.org. Accessed 10 fev. 2020.

Ferreira NGP, Oliveira APA, Paz MF, Leite RSR. Produção de invertase por Lichtheimia ramosa. In: XIX Simpósio Nacional de Bioprocessos, 2013, Foz do Iguaçu, Brasil, 2013.

Garcia NFL, Santos FRS, Bocchini DA, Paz, MF, Fonseca GG, Leite RSR. Catalytic properties of cellulases and hemicellulases produced by Lichtheimia ramosa: Potential for sugarcane bagasse saccharification. Industrial Crops and Products, v. 122, p. 49-56, 2018.

Ghose T. K. Measurement of cellulase activities. Pure and Applied Chemistry, v. 59, p. 257-268, 1987.

Gonçalves FA, Sanjinez-Argandoña EJ, Fonseca GG. Utilization of agro-industrial residues and municipal waste of plant origin for cellulosic ethanol production. Journal of Environmental Protection, v. 2, p. 1303-1309, 2011.

Gonçalves FA, Leite RSR, Rodrigues A, Sanjinez-Argandoña EJ, Fonseca GG. Isolation, identification and characterization of a novel high level $\beta$-glucosidase-producing Lichtheimia ramosa strain. Biocatalysis and Agricultural Biotechnology, v. 2, p. 377-384, 2013a.

Gonçalves FA, Sanjinez-Argandona EJ, Fonseca GG. Production of cellulosic ethanol and its co-products using different substrates, pretreatments, microorganisms and bioprocesses. Natural Science, v. 5, p. 11-25, 2013b.

Gonçalves FA, Ruiz HA, dos Santos ES, Teixeira JA, de Macedo GR. Produção de etanol através de Saccharomyces cerevisiae PE2 usando fibra e casca de coco maduro, casca de coco verde e cacto pré-tratados. In: $27^{\circ}$ Congresso Brasileiro de Microbiologia. Natal, Brasil, 2013c.

Gonçalves FA, Ruiz HA, Nogueira CC, dos Santos ES, Teixeira JA, de Macedo GR. Comparison of delignified coconuts waste and cactus for fuel-ethanol production by the simultaneous and semi-simultaneous saccharification and fermentation strategies. Fuel, v. 131, p. 66-76, 2014.

Gonçalves FA, Ruiz HA, dos Santos ES, Teixeira JA, de Macedo GR. Use of cultivars of low cost, agroindustrial and urban waste in the production of cellulosic ethanol in Brazil: A proposal to utilization of microdistillery. Renewable and Sustainable Energy Reviews. v. 50, p. 1287-1303, 2015.

Gonçalves FA, Ruiz HA, dos Santos ES, Teixeira JA, de Macedo GR. Bioethanol production by Saccharomyces cerevisiae, Pichia stipitis and Zymomonas mobilis from delignified coconut fibre mature and lignin extraction according to biorefinery concept. Renewable Energy, v. 94, p. 353-365, 2016. 
Gonçalves FA, Ruiz HA, dos Santos ES, Teixeira JA, de Macedo GR. Valorization, Comparison and Characterization of Coconuts Waste and Cactus in a Biorefinery Context Using $\mathrm{NaClO}_{2}-\mathrm{C}_{2} \mathrm{H}_{4} \mathrm{O}_{2}$ and Sequential $\mathrm{NaClO}_{2}-\mathrm{C}_{2} \mathrm{H}_{4} \mathrm{O}_{2}$ /Autohydrolysis Pretreatment. Waste and Biomass Valorization. v. 10, p. 2249-2262, 2019.

Gupta R, Lee YY. In: Wyman CE (ed) Aqueous pretreatment of plant biomass for biological and chemical conversion to fuels and chemicals, John Wiley and Sons, Inc., New Jersey, 2013.

IBGE - Instituto Brasileiro de Geografia e Estatística. Levantamento Sistemático da produção Agrícola: pesquisa mensal de previsão e acompanhamento das safras agrícolas no ano civil/Fundação Instituto Brasileiro de Geografia e Estatística. IBGE, Rio de Janeiro, 2020.

Leite RSR, Bocchini DA, Martins ES, Silva D, Gomes E, Da Silva R. Production of cellulolytic and hemicellulolytic enzymes from Aureobasidium pulluans on solid state fermentation. Biotechnology and Applied Biochemistry, v. 136-140, p. 281-288, 2007.

Mandels M, Andreotti R, Roche C. Measurement of saccharifying cellulase. Biotechnology and Bioengineering Symposium, v. 6, p. 21-23, 1976.

Mesa L, González E, Romero I, Ruiz E, Cara C, Castro E. Comparison of process configurations for ethanol production from two-step pretreated sugarcane bagasse. Chemical Engineering Journal, v. 175, p. 185-191, 2011.

Pandey A. Solid-state fermentation. Biochemical Engineering Journal, v. 13, p. 81-84, 2003.

Pandit S, Lawrence K, Singh A, Singh S, Lawrence R. Cellulase production by Aspergillus flavus and saccharification of wheat straw. International Journal of Scientific and Engineering Research, v. 4, n. 6, p. 1965-1971, 2013.

Rabelo SC, Amezquita Fonseca NA, Andrade RR, Maciel Filho R, Costa AC. Ethanol production from enzymatic hydrolysis of sugarcane bagasse pretreated with lime and alkaline hydrogen peroxide. Biomass Bioenergy, v. 35, p. 26002607, 2011.

Rana V, Eckard AD, Teller P, Ahring BK. On-site enzymes produced from Trichoderma reesei RUT-C30 and Aspergillus saccharolyticus for hydrolysis of wet exploded corn stover and loblolly pine. Bioresource Technology, v. 154, p. 282-289, 2014.

Rocha NRAF, Barros MA, Fischer J, Coutinho Filho U, Cardoso VL. Ethanol production from agroindustrial biomass using a crude enzyme complex produced by Aspergillus niger. Renewable Energy, v. 57, p. 432-435, 2013.

Roslan MA, Yee PL, Shah UKM, Aziz SA, Hassan MA. Production of bioethanol from rice straw using cellulases by local Aspergillus sp. International Journal of Agricultural Research, v. 6, p. 188-193, 2011

Rostagno HS. Tabelas brasileiras para aves e suínos: composição de alimentos e exigências nutricionais. Viçosa, Minas Gerais, 2011.

Saini JK, Anurag RK, Arya A, Kumbhar BK, Tewari L. Optimization of saccharification of sweet sorghum bagasse using response surface methodology. Industrial Crops and Products, v. 44, p. 211-219, 2013.
Santos JRA, Gouveia ER. Produção de bioetanol de bagaço de cana-de-açúcar. Revista Brasileira de Produtos Agroindustriais, v. 11, p. 27-33, 2009.

Santos JRA, Souto-Maior AM, Gouveia ER, Martin C. Comparação entre processos em SHF e em SSF de bagaço de cana-de-açúcar para a produção de etanol por Saccharomyces cerevisiae. Química Nova, v. 33, p. 904-908, 2010.

Schwartze VU, Hoffman K, Nyilasi I, Papp T, Vágvölgyi C, de Hoog S, Voigt K, Jacobsen ID. Lichtheimia species exhibit differences in virulence potential. PLoS One v. 7, p. e40908, 2012.

Selig M, Weiss Y, Ji Y. Enzyme saccharification of lignocellulosic biomass. National Renewable Energy Laboratory. Golden, Colorado, 2008.

Shen J, Agblevor FA. Modeling semi-simultaneous saccharification and fermentation of ethanol production from cellulose. Biomass Bioenergy, v. 34, p. 1098-1107, 2010.

Silva CAA, Lacerda MPF, Leite RSR, Fonseca GG. Production of enzymes from Lichtheimia ramosa using Brazilian savannah fruit wastes as substrate on solid state bioprocesses. Electronic Journal of Biotechnology, v. 16, n. 5, 2013.

Silva CAA, Lacerda MPF, Leite RSR, Fonseca GG. Physiology of Lichtheimia ramosa obtained by solid-state bioprocess using fruit wastes as substrate. Bioprocess and Biosystems Engineering, v. 37, p. 727-734, 2014.

Sindhu R, Kuttiraja M, Binod P, Sukumaran RK, Pandey A. Physicochemical characterization of alkali pretreated sugarcane tops and optimization of enzymatic saccharification using response surface methodology. Renewable Energy, v. 62, p. 362-368, 2014.

Singh A, Bishnoi NR. Enzymatic hydrolysis optimization of microwave alkali pretreated wheat straw and ethanol production by yeast. Bioresource Technology, v. 108, p. 94-101, 2012.

Singh A, Singh N, Bishnoi NR. Enzymatic hydrolysis of chemical pretreated rice straw by Aspergillus niger and Aspergillus heteromorphous. Journal of Scientific and Industrial Research, v. 69, p. 232-237, 2010.

Singhania RR, Patel AK, Sukumaran RK, Larroche C, Pandey A. Role and significance of beta-glucosidases in the hydrolysis of cellulose for bioethanol production. Bioresource Technology, v. 127, p. 500-507, 2013.

Wang G, Liu C, Hong J, Ma Y, Zhang K, Huang X et al. Comparison of process configurations for ethanol production from acid- and alkali-pretreated corncob by Saccharomyces cerevisiae strains with and without $\beta$-glucosidase expression. Bioresource Technology, v. 142, p. 154-161, 2013.

Wang Z, Keshwani DR, Redding AP, Cheng JJ. Sodium hydroxide pretreatment and enzymatic hydrolysis of coastal Bermuda grass. Bioresource Technology, v. 101, p. 3583$3585,2010$.

Zhou J, Wang YH, Chu J, Luo LZ, Zhuang YP, Zhang SL. Optimization of cellulase mixture for efficient hydrolysis of steam-exploded corn stover by statistically designed experiments. Bioresource Technology, v. 100, p. 819-825, 2009.

Zimbardi ALRL, Sehn C, Meleiro LP, Souza FHM, Masui DC, Nozawa MSF et al. Optimization of $\beta$-glucosidase, $\beta$ xylosidase and xylanase production by Colletotrichum 
graminicola under solid-state fermentation and application in raw sugarcane trash saccharification. International Journal of Molecular Sciences, v. 14, p. 2875-2902, 2013. 